\title{
Arap Belâgatında İktibas Sanatı
}

\section{İbrahim Kara*}

Atıf/C: Kara, İbrahim, Arap Belâgatında İktibas Sanatı, Artuklu Akademi, 2021/8 (1), 77-98.

Öz: İktibas, Arap belâgatının bedî́ ilminde ele alınan bir sanattır. Genel olarak iktibas denilince nazımda veya nesirde ayet ve hadislerden yapılan alıntı akla gelmektedir. İslamiyet'in gelmesiyle birlikte Kur'ân-1 Kerîm ve hadis-i şerifler Arap toplumunda birçok alanda olduğu gibi edebiyatta da değişimlere sebep olmuştur. İslamiyet'in getirdiği değerlerden etkilenen edebiyatçılar şiirlerinde veya düzyazılarında duygu ve düşüncelerini aktarırlarken eserlerini lafız ve mana yönünden güçlendirmek için ayet ve hadislerden alıntılar yapmışlardır. $\mathrm{Bu}$ çalışma, iktibas sanatının Arap belâgatındaki konumunu etimolojik ve tarihsel süreç de göz önünde bulundurularak incelemek amaciyla yapılmaktadır. Böylece Arap belâgatına ilgi duyanlar iktibas sanatını örnekleriyle birlikte daha yakından görüp öğrenebileceklerdir.

Anahtar Kelimeler: Arapça, Edebiyat, Belâgat, İktibas, Bedî̃.

The Art of Quoting in Arabic Rhetoric

Citation/@: Kara, İbrahim, The Art of Quoting in Arabic Rhetoric, Artuklu Akademi, 2021/8 (1), 77-98.

\begin{abstract}
Quoting is an art that is handled in the eloquence science of the Arabic rhetoric. Generally, when quoting is mentioned, quotations from verses and hadiths come to mind in poetic style or prose. With the advent of Islam, the Quran and hadiths caused changes in literature as well as in many other fields in Arab society. The writers who were influenced by the values brought by Islam made quotations from verses and hadiths in order to strengthen their works in terms of wording and meaning while conveying their feelings and thoughts in their poems or prose. This study in your hand is intended to examine the position of the art of quotation in Arabic rhetoric, taking into account the etymological and historical process. Thus, those who are interested in Arabic rhetoric will be able to see and learn the art of quoting more closely along with its examples.
\end{abstract}

Keywords: Arabic, Literature, Rhetoric, Quotation, Eloquence.

Arş. Gör., Kırıkkale Üniversitesi İslami İlimler Fakültesi Arap Dili ve Belagati Anabilim Dalı, ibrahimkara@kku.edu.tr 


\section{Giriş}

Medeniyet oluşumunda ve gelişimindeki en önemli faktörlerden birisi dindir. Nitekim yeni bir inancs benimseyen bir toplumun hayatında o inancın getirdiği birtakım yenilikler kaçınılmazdır. Kur'ân-1 Kerîm’in inmesiyle İslam dinini benimseyen insanlar İslam medeniyet ve kültürünü inşa etmişlerdir. Bu medeniyet ve kültürün en önemli unsurlarından birisi de kuşkusuz edebiyattır. İslam inancı gönüllerde yerini bulunca duygu ve düşüncelerde değişimler olmuştur. Bu duygu ve düşüncelerin en önemli ifade aracı olan edebiyatta hem şekil hem de muhteva olarak bir yenilik meydana gelmiştir. Nitekim şairler ve yazarlar eserlerinde, benimsedikleri dinin temel iki kaynağı olan Kur'ân ve hadislerden iktibaslar yapmışlardır.

İktibas, Arap belâgatının bedî‘ ilminde muhassinât-1 lafziyye (sözle ilgili süsleme sanatları) konuları arasında ele alınmaktadır. Bu makalede iktibas kavramının öncelikle sözlük ve terim anlamları verilecektir. Ardından bu sanatın belâgat ilminde ifade ettiği anlam, iktibasın kullanılmasının dindeki yeri, iktibasın terimleşme süreci ve iktibasla ilgili sanatlar üzerinde durulacaktır. Son olarak da iktibasın edebi değeri incelenecektir.

\section{Etimolojik Olarak İktibas}

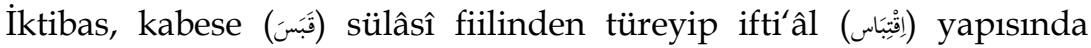

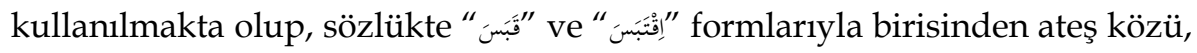
hayır, ilim istemek ve birisinin ilminden istifade etmek gibi anlamlara

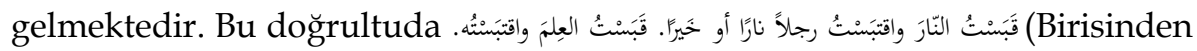
ateş ya da hayır, ilim istedim anlamlarında kullanılmaktadır.) ${ }^{1}$

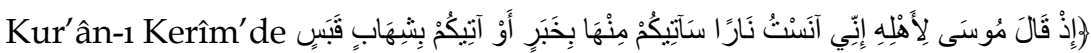
“'Bir zamanlar Mûsâ, ailesine, '(Şu uzakta) bir ateş bulunduğunu fark ettim. Size oradan bir haber ya da 1sınmanız için ondan bir parça kor

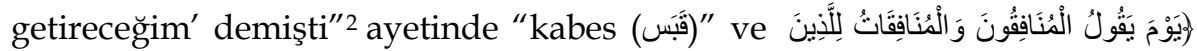

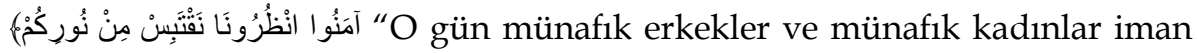
edenlere şöyle diyecekler: 'Bizi bekleyin de yetişip nurunuzdan bir parça

el-Halîl b. Ahmed el-Ferâhîdî, Kitâbü'l-'ayn, thk. Mehdî el-Mahzûmî, (y.y.: Dâru ve Mektebetü Hilâl, tsz.), V, 86; Ebü'l-Fazl Muhammed b. Mükerrem İbn Manzûr, Lisânü'l-'Arab, (Beyrut: Dâru Sâdir, 1993), VI, 167; Muhammed Murtezâ el-Hüseynî ez-Zebîdî, Tâcu'l-'arûs min cevâhiri'l-kâmûs, thk. Abdüssettâr Ahmed Ferrâc, (Kuveyt: Dârü'1-Hidâye, 2004), XVI, 350-353.

2 en-Neml, 27/7. 


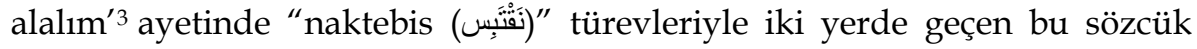
"ateş közü/kor ve 1şıktan faydalanmak/aydınlanmak anlamlarında kullanılmıştır. ${ }^{4}$

\section{Belâgat İlminde İktibas}

Belâgat ilminde iktibas, mütekellimin sözlerinde Kur'ân-1 Kerim, hadis-i şerif, atasözleri, büyük edebiyatçların sözleri ve diğer şairlerin şiirlerinden alıntı yapmasıdır. Bu sanatta önemli olan iktibasın yapıldığının lafızda açık bir şekilde anlaşılmamasıdır. Dolayısıyla "Yüce Allah şöyle buyurdu", "Hz. Peygamber şöyle buyurdu" veya "Hadis-i şerifte şöyle buyrulmuştur" tarzındaki alıntılar iktibas olarak kabul edilemez. ${ }^{5}$ İktibas sanatından bahsedebilmek için yapılan alıntının en az bir terkip olması lazımdır. Bu nedenle ayet ya da hadisten sadece bir kelime alınması iktibas olarak kabul edilmediği gibi, uzun alıntılar da makbul sayılmaz. ${ }^{6}$ Bu sanat yapılırken şiirde kafiye ve vezin zaruretine binaen iktibas edilen metni biraz değiştirmek uygun görülmüştür. ${ }^{7}$ Ayet ve hadis iktibası yapılırken metnin tamamı alıntılanıyorsa buna "tam iktibas", yarısı veya bir kısmı alıntılanıyorsa da buna "nâkıs iktibas" denilmiştir. ${ }^{8}$

İbnu'r-Rûmî'nin (ö. 283/896) aşağ1daki beyti Kur'ân-1 Kerîm'den yapılan iktibasa güzel bir örnek olarak sunulabilir: ${ }^{9}$

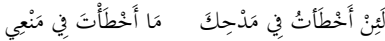

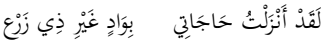

Ben seni övmekte hata yapmışsam da

Sen beni (iyilikten) mahrum etmede hata etmedin

Ben gerçekten ihtiyaçlarımı,

"Ekin bitmez bir vadiye" bırakmışım.

el-Hadîd, 57/13.

4 er-Râgib el-Isfahânî, Müfradâtü elfâzi'l-Kur'ân, thk. Safvân Adnan Râvevdî, (Dimaşk: Dârü'1 Kalem, 1997), 652.

5 el-Hatîb el-Kazvînî, el-Îzâh fì 'ulûmi'l-belâga, thk. Muhammed Abdülkâdir el-Fâzilî, (Beyrut: elMektebetü'l-'Asriyye, 2009), 406-413; Sa'duddîn Mesud b. Ömer et-Teftâzânî, el-Mutavvel şerhu telhîsi miftâhi'l-'ulûm, thk. Abdülhamîd Hindâvî, (Beyrut-Lübnan: Dârü'l-Kütübi'l-'Illmiyye, 2007), 721-722; etTeftâzânî, Muhtasaru'l-me'ânî, thk. Hind Mahmûd Hasan, (Pakistan: Mektebetü'l-Büşrâ, 2012), II, 323-333; Abdurrahman Hasan Habenneke el-Meydânî, el-Belâgatü'l-'arabiyye üsüsühâ ve 'ulûmuhâ ve fünûnuhâ ve suverun min tatbîkâtihâ bi-heykelin cedidin min tarifin ve telîd, (Dimaşk: Dârü'l-Kalem, 2013), 536; Ali Bulut, Belâgat Meânî-Beyân-Bedî̀, (İstanbul: İFAV, 2014), 326-327.

6 Bulut, Belâgat, 327.

7 Nusrettin Bolelli, Belâgat Meânî-Beyân-Bedî’ İlimleri, (İstanbul: İFAV, 2015), 435.

8 Ziyâeddîn İbnü'l-Esîr, el-Meselü's-sâir fi edebi'l-kâtibi ve'ş-şấ'ir, thk. Muhammed Muhyiddîn Abdülhâmîd, (Beyrut: Mektebetü'l-'Asriyye li't-Tıbâ'a ve'n-Neşr, 1999), II, 323; Abdussamed Yeşildă̆, "Arap Şiirinde Ayet İktibası", Şarkiyat Mecmuası, 27/2 (2015): 56.

9 Kazvînî, el-Î́zâh, 409. 


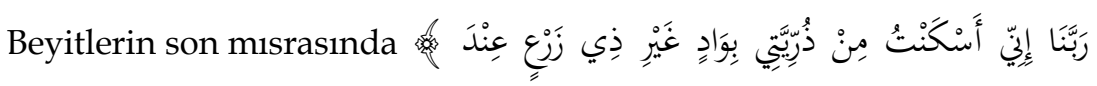
“Rabbimiz! Ben çocuklarımdan bazısını, senin kutsal evinin (Kâbe'nin) yanında ekin bitmez bir vadiye yerleştirdim" ${ }^{10}$ ayetinden iktibas yapilmıştır.

es-Sâhib b. 'Abbâd'ın (öl. 385/995) aşağıdaki beytinde de hadis-i şeriften iktibas yapılmıştır: ${ }^{11}$

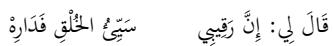

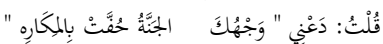

Bana 'takipçim kötü ahlaklıdır. Ona yumuşak davran,' dedi.

Ben de 'Beni boş ver! Cennet yüzün (takipçi gibi) nefse hoş gelmeyen şeylerle kuşatılmıştır.' dedim. ${ }^{12}$

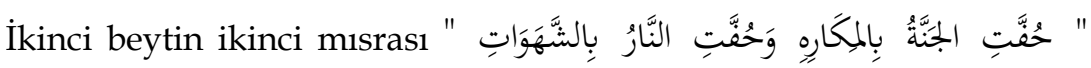
"Cennet, nefsin hoşlanmadiğı şeylerle, cehennem ise nefsî arzu ve isteklerle kuşatılmıştır" ${ }^{13}$ hadis-i şerifinden alıntıdır.

es-Sâhib b. 'Abbâd'1 yaptığı bu iktibas nedeniyle Telhîs şarihlerinden Bahâeddîn es-Sübkî (öl. 763/1362) eleştirmiştir. Ona göre bu türlü ibarelerin Kur'ân-1 Kerîm ve hadis-i şeriften alınarak bir beyitte ya da misrada kullanılması hoş değildir ve muttakilere yakışmaz. ${ }^{14}$ Ayrıca modern belâgatçılardan Meydânî, dünyevî amaçlar için Kur'ân-1 Kerîm ve hadis-i şeriften alıntı yapılmasını, anlamın tahrifine yol açacağı endişesiyle doğru bulmamaktadir. $^{15}$

Hz. Peygamber'in hadisi incelendiğinde beyitte kastedilen manadan uzak olduğu kolaylıkla anlaşılabilir. İlgili beyit, Hz. Peygamber'in kastettiği dinî anlam ve gayeden uzak, övgü maksadıyla söylenmiştir. Yapılan alıntı hadis-i şerifle aynı anlamda kullanılmasa bile dinî değerlerin özüne aykırı olmadığı sürece kabul edilebilir.

İbrahim, 14/37.

11 Ahmed b. Ali b. Abdilkâfî Ebû Hâmid Bahâeddîn es-Sübkî, 'Arûsu'l-efrâh fî şerhi Telhîsi'l-miftâh, thk. Abdülhamîd Hindâvî, Beyrut, el-Mektebetü'l-'Asriyye, 2003, II, 333; Abdülmüte'âl es-Sa'îdî, Buğyetü'lİzâh li Telhîsi'l-miftâh fí 'ulûmi'l-belâga, (y.y, Mektebetü'l-Âdâb, 2005), IV, 117.

12 Beytin anlamı için bkz. Mehmed Zihnî, el-Kavlü'l-ceyyid fî şerhi ebyâti't-Telhîs ve Şerhayhi ve Hâşiyeti'sSeyyid, (İstanbul: Matbaa-i Âmire, 1910), 484.

13 Müslim b. el-Haccâc, Sahîhu Müslim, thk. Muhammed Fuâd Abdülbâkî, (Beyrut: Dâru İhyâi't-Türâsi'1'Arabî, tsz.), IV, 2174.

14 Sübkî, 'Arûsu'l-efrâh, II, 334.

15 Meydânî, el-Belâgatü'l-'arabiyye, II, 536-538. 
el-Kâdî el-Fâzıl'ın (ö. 596/1200) aşağıdaki sözü Kur'ân-1 Kerîm'den yapılan iktibasa bir örnektir: ${ }^{16}$

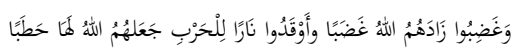

Öfkelendiler, Allah onların öfkelerini artırsın. Savaş için ateş yaktılar, (savaşa zemin hazırladılar) Allah onları o savaşın odunu yapsin!

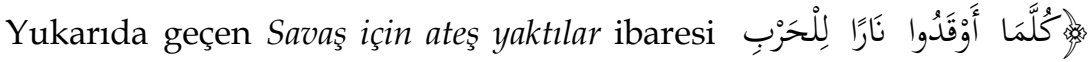
“ Ne zaman savaş ateşini tutuşturmuşlarsa Allah onu söndürmüşşür "17 ayetinden iktibastır.

İbn Senâ el-Mülk'ün (öl. 608/1212) şu beytinde de Kur'ân-1 Kerîm'den iktibas yapılmıştır: ${ }^{18}$

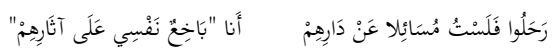

Ayrıldılar. Gittikleri yurtlarını sormam.

Arkalarından üzülerek adeta kendimi tüketeceğim.

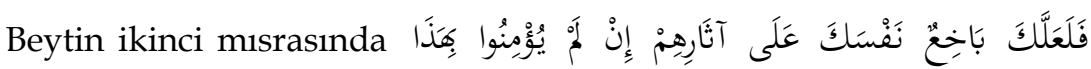
“Demek sen, bu söze (Kur'ân'a) inanmazlarsa, arkalarından üzülerek adeta kendini tüketeceksin." ayetinden iktibas yapılmıştır. ${ }^{19}$

İbn Nübâte' nin (ö. 768/1366) bir hutbesinde olduğu gibi: ${ }^{20}$

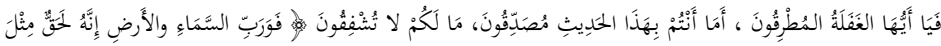

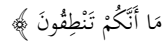

Ey başı öne eğik gafiller! Siz bu söze inanmıor musunuz? Size ne oluyor da bu sözden çekinmiyorsunuz? “Göğün ve yerin Rabbine yemin olsun ki o (size söylediklerim) birbirinizle konuşmalarınız gibi mutlaka gerçektir.

\footnotetext{
6 Kazvînî, el-Îzâh, 407; Hikmet Akdemir, Belâgat Meânî-Beyân-Bedî̀, (İstanbul: Nizamiye Akademi, 2016), 332.

17 el-Mâide, $5 / 64$.

18 İbn Hicce el-Hamevî, Hizânetü'l-edeb ve ğâyetü'l-ereb, thk. 'İsâm Şakyû, (Beyrut: Mektebetü'l-Hilâl, 2004), II, 457.

19 el-Kehf, $18 / 6$.

20 İbnü'l-Esîr, el-Meselü's-sâir, II, 328; Ahmed b. Ali el-Kalkaşendî, Subhu'l-a'ş̧â fì sinâ'ati'l-inşâ,, (Beyrut: Dârü'l-Kütübi'l-'ilmiyye, tsz.), I, 237.
} 


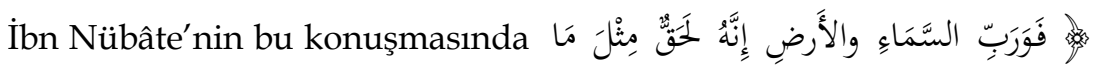
“Göğün ve yerin Rabbine yemin olsun ki o (size söylediklerim) birbirinizle konuşmalarını gibi mutlaka gerçektir" 21 ayetinden iktibas yapılmıştır.

Ebû Ca'fer el-Endelusî́nin (öl. 779/1378) aşağıdaki beyitlerinde hadisi şeriften iktibas yapılmıştır: ${ }^{22}$

$$
\begin{aligned}
& \text { قَلَّما يُرعَعَى غَريبُ الوَطَنْ لا تُعَادِ النَّاسَ في أَوْطانِهِمُ }
\end{aligned}
$$

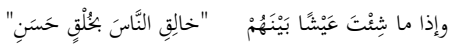

İnsanlara kendi vatanlarında düşmanlık etme Vatanın yabancısı çok az gözetilir (önem verilir) Onların arasında yaşamak istersen "İnsanlara güzel ahlakla davran".

Yukarıdaki beyitte zikredilen "Insanlara güzel ahlakla davran" ibaresi

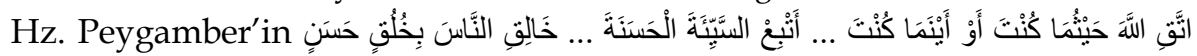
"Her nerede olursan ol Allah'a karşı gelmekten sakın. Kötülüğ̈̈n ardından hemen bir iyilik yap. Insanlara güzel ahlakla davran" hadisinden alıntıdır. ${ }^{23}$

\section{III. İktibasın Dinî Hükmü}

İktibasın dinî hükmü konusunda çeşitli görüşler bulunmaktadır. Hutbe hitabe, mev'iza ahid, na't gibi iktibaslar makbul; gazel, risale ve kıssalardaki iktibaslar mubah sayılmış; Allah'ın zatına nispet ettiği ifadeleri insana uyarlayarak iktibasta bulunmak veya ciddiyetten uzak şiirlerde, müstehcen nazımlar içinde Kur'ân'dan ve hadisten iktibaslar yapmak caiz görülmemiştir. $^{24}$

Celâleddîn es-Süyûtî (öl. 911/1505), Malikîlerin iktibasın haram kılınması ve kınanması noktasında aşırıya kaçtıkları görüşündedir. Hatta

21 ez-Zâriyât, 51/23.

22 Şehabettin Ahmed b. Muhammed el-Makrî et-Tilimsânî, Nefhu't-tîb min gusni'l-endülüsi'r-ratîb, thk. İhsan Abbâs, (Beyrut: Dâru Sâdir, 1997), V, 375; Ali el-Cârim, Mustafa el-Emîn, el-Belâgatü'l-vâzıha, (Dimaşk: Dâru'l-Kıbâ, tsz.), 354.

23 Ahmed b. Hanbel, Müsned, thk. Şuayb el-Arnût vd. (y.y., Müessesetü'r-risâle, 1999), XXXVI, 381.

24 Safiyyüddin el-Hillî, Şerhu'l-kâfiyeti'l-bedî'iyye fî̀ 'ulûmi'l-belâga ve mehâsini'l-bedî', thk. Nesîb Neşâvî, (Beyrut: Dâru Sâdir, 1992), 326-328; Hamevî, Hizânetü'l-edeb, I, 303; İsmail Durmuş, "İktibas", Türkiye Diyanet Vakfi İslâm Ansiklopedisi, (İstanbul, Türkiye Diyanet Vakfı, 2000), XXII, 52. 
onların iktibası küfür derecesinde tehlikeli gördüklerini ifade etmektedir. ${ }^{25}$ Mâlikî fakihi Ebû Bekr el-Ebherî (ö. 375/986) ise iktibası şiir için mekruh, nesir için caiz görmüştür. Bunun yanı sıra Şafî̂ mezhebinde şiirde veya nesirde iktibasa cevaz verilmektedir. ${ }^{26}$

İbn Hicce el-Hamevî́nin Hizânetü'l-edeb'inde kabul edilmeyen iktibasa aşağıdaki beyitler örnek gösterilmiştir. ${ }^{27}$

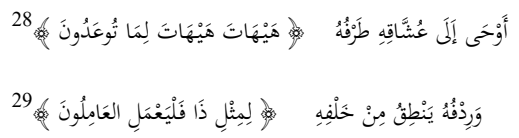

(Sevgilinin) Bakışları sevenlerine işaret etti ki

"Size vaat olunan şey ne kadar da uzak" (Boşuna ümitlenmeyin!)

Arkasından kalçaları ise şöyle söyler

"Çalışanlar böylesi için çalışsınlar".

Şiirde sevgilinin bakışları sevenlerini ümitsizliğe sevk ederken vücut özellikleri ise tam aksine sevenlerini ümitlendirmektedir. Şiirde Kur'ân-1 Kerîm'den iki iktibas yapılmıştır. Yapılan ilk iktibasta sevgilinin bakışlarının tasviriyle ilgili bir anlatım söz konusuyken ikincisinde vücudunun bir bölümünün tasviriyle ilgili iktibas yapılmıştır. Allah kelamının böyle dünyevî gayeler ve müstehcen tasvirler için kullanılması hoş görülemez.

Sonuç olarak iktibasın caiz olup olmaması birkaç nedene bağlanabilir. Kişinin ihlas ve samimiyet sahibi olması, kalbinde güzel anlamlar barındırması ve dinî değerlere saygılı olması gerekmektedir. Kur'ân-ı Kerîm ve hadis-i şeriflerden yapılan iktibasta önemli olan mananın korunması, Allah ve resulüne saygıdır. Bu ölçülere dikkat edildiğinde edebi bir sanat değeri taşıyan iktibas, ifadeye güzellik kattığı gibi muhatapların zihinlerinde canlılık hissi uyandıracaktır.

\section{IV. İktibas Sanatının Terimleşme Süreci}

25 Celâleddîn es-Süyûtî, Şerhu 'ukûdi'l-cümân fi'l-me'ânî ve'l-beyân, thk. İbrahim el-Hamedâni, Emîn Lukmân el-Habbâr, (Beyrut: Dâru'1-Kütübi'1-'İlmiyye, 2011), 378-379; Kutaiba Farhat, “Arap Dili Edebiyatında Kur'an'dan İktibas", (Yayımlanmamış Doktora Tezi, Ankara Yıldırım Beyazıt Üniversitesi Sosyal Bilimler Enstitüsü, Ankara 2019), 58.

26 Celâleddîn es-Süyûtî, el-İtkân fí 'ulûmi'l-Kur'ân, thk. Merkezu'd-dirâsâti'l-Kur'âniyye, (y.y., Vezâratü'şşuûni'l-İslâmiyye ve'l-evkâf ve'd-Da'veti ve'1-İrşâd, tsz.) 719-720; Yeşildağ, "Arap Şiirinde Ayet İktibası”, 48.

27 Hamevî, Hizânetü'l-edeb, II, 455.

28 el-Mü'minûn, 23/36.

29 es-Sâffât, 37/61. 
İslam'ın ilk zamanlarından beri iktibas sanatı Araplar tarafından bilinen bir husustur. Hz. Peygamber dualarında ve hutbelerinde Kur'ân-1 Kerîm'den iktibaslar yapmıştır. Abdullah b. Sâib'den gelen rivayete göre Hz. Peygamber Safa ve Merve arasında "Rabbimiz! Bize dünyada da iyilik ver, ahirette de iyilik ver ve bizi ateş azabından koru" ${ }^{30}$ şeklinde dua ederek Kur'ân-1 Kerîm'den iktibas yapmıştır. ${ }^{31}$ Ayrıca Ebû Hureyre'den rivayet edilen bir başka hadiste Hz.

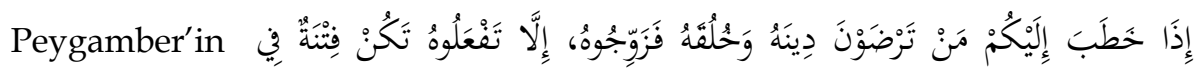
“ " Dindarlığını ve ahlakını beğendiğiniz bir kişi size (kız istemek için) gelirse onu evlendirin. Bunu yapmazsanız yeryüzünde bir

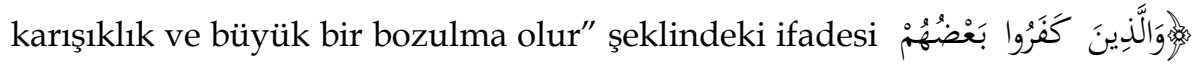

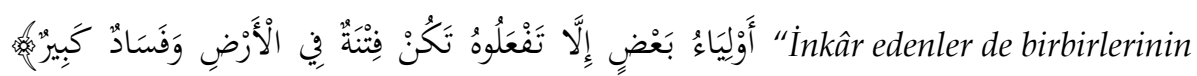
velileridirler. Eğer siz bunların gereğini yapmazsanız, yeryüzünde bir karışıklı ve büyük bir bozulma olur' ${ }^{\prime 32}$ ayetinden iktibastır. ${ }^{33}$

Kur'ân-1 Kerîm'den iktibasın olmadığı bir hutbe " "بَتُرَّ" (hayırsız) olarak nitelenmiştir. İmrân b. Hittân'ın Ziyâd b. Ebîh'in (ya da İbn Ziyâd) huzurunda okuduğu bir hutbe ediplerce beğenilmiş ve bu hutbede Kur'ân'dan bir iktibas yapılmış olsaydı bu şahsın Arapların en büyük hatibi olabileceği kanaatine varılmıştır. ${ }^{34}$

Mütekellim ve müfessir yönüyle bilinen dil âlimi Fahreddîn er-Râzî

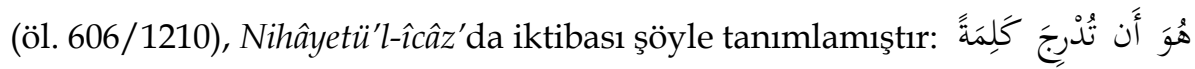
(Sözü süslemek ve değerini artırmak için söze Kur'ân'dan bir kelime ya da ayetin eklenmesidir.) ${ }^{35}$

\footnotetext{
el-Bakara, 2/201.

1 Ebû Dâvûd es-Sicistânî, Sünenü Ebî Dâvûd, (Beyrut: Dârü'l-Kütübi'l-'İlmiyye, tsz.), II, 119.

el-Enfâl, 8/73.

3 İbnü'l-Kattân el-Mağribî, Beyânü'l-vehm ve'l-îhâm fî̀ kitabi'l-ahkâm, thk. Hüseyin Ayet Sa'îd, (Riyad: Dâru Taybe, 1997), V, 206.

34 Ebû Osman Amr b. Bahr el-Câhız, el-Beyân ve't-Tebyîn, thk. Muvaffak Şihâbuddîn, (Beyrut: Dârü'1Kütübi'l-'İlmiyye, 2009), I, 87; Durmuş, “İktibas”, 52.

35 Fahreddîn er-Râzî, Nihâyetü'l-îcâz fí dirâyeti'l-I'câz, thk. Nasrullah Hacımüftüoğlu, (Beyrut: Dâru Sâdir, 2004), 173.
} 
Fahreddîn er-Râzî’den önceki dönemde ise bu sanat tazmîn olarak bilinmekteydi. ${ }^{36}$

Şihabüddîn el-Halebî (ö. 725/1325) hüsnü't-tazmîn başlı̆̆ı altında

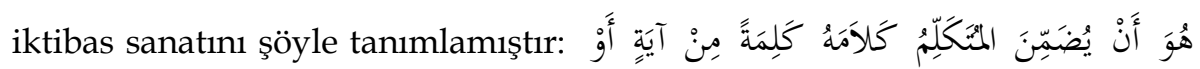
حَدِيثٍ أَوْ مَثَلِل سَائرٍ أَوْ بَيْتِ شِعْرِ (Söz sahibinin sözüne Kur'ân, hadis, mesel ya da beyitten bir ifadeyi katmasıdır.) el-Halebî bu tanımında iktibas yerine tazmîn lafzını kullanmıştır. ${ }^{37}$ Benzer tanımı iktibas başlığı altında en-Nüveyrî (öl. 733/1333) de yapmiştır. ${ }^{38}$

İbn Kayyim el-Cevziyye (ö. 751/1350) iktibasın tazmîn olarak da

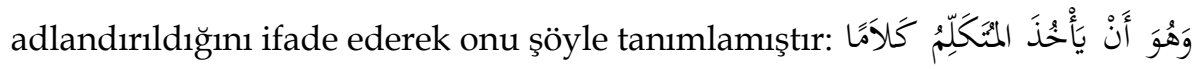

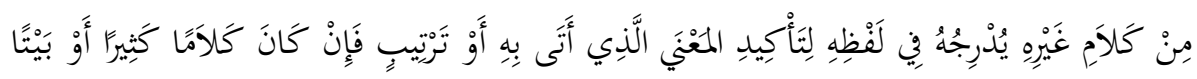
Söz sahibinin başkasının sözünden bir sözü ortaya koyduğu anlamı pekiştirmek ya da düzenlemek için kendi ifadelerine eklemesidir. Eğer alıntı uzun bir söz ya da bir beyit olursa tazmîn olarak adlandırılır. Eğer alıntı kısa bir söz ya da bir beytin yarısı olursa buna $\hat{\imath} d \hat{a}^{\prime}$ denilir.) ${ }^{39}$

el-Cevziyye burada yapılan alıntının uzunluk ve kısalığını temel almıştır. Nitekim yapılan alıntı uzun bir söz ya da tam bir beyitten müteşekkil ise buna tazmîn derken, kısa bir söz veya bir beytin yarısı şeklindeki alıntıya da $\hat{\imath} d \hat{a}^{\prime}$ terimini kullanmıştır.

Hatîb el-Kazvînî, (öl. 739/1338) Halebî ve Nüveyrî́nin tanımlarının benzerini yapmakla birlikte tanıma لَا عَلَى أَنَّهُ مِنْهُ (iktibasın ayet veya hadis olduğunun belli olmaması) kaydını eklemiştir. Kazvînî, el-Harîrî'nin كَلْمْحِ البَصَرِ (Göz açıp kapanıncaya kadar, hatta daha kısa bir zaman içinde şiir okudu ve insanları hayrete düşürdü.) nesrinden örnek vermiştir. ${ }^{40}$

\footnotetext{
36 Abdulmuhsin b. Abdilaziz el-'Asker, el-İktibâs envâ'uh ve ahkâmuh, (Riyad: Mektebetü Dâri'l-Minhâc, 2004), 13.

37 Şihabüddîn el-Halebî, Hüsnü't-tevessül ilâ sına'ati't-terassül, (Mısır: el-Matbaatü'l-Vehbiyye, 1881), 61.

38 Ebü'l-Abbâs Şihâbüddîn en-Nüveyrî, Nihâyetü'l-ereb fî fünûni'l-edeb, (Kahire: Dârü'l-Kütüb ve'l-Vesâiki'1Kavmiyye, 2002), VII, 182.

39 Ebû Abdillâh Şemsüddîn Muhammed b. Ebî Bekr b. Eyyûb ez-Züraî, el-Fevâid el-Müşevoik ilâ 'ulûmi'lKur'ân ve 'ilmi'l-beyân, (Lübnan: Dâru'l-Kutubi'l-'Ilmiyye, tsz.), 117.

40 Kazvînî, el-Îzâh, 406; Ahmed Matlûb, Mu'cemu'l-mustalahâti'l-belâgryye ve tatavvuruhâ, (y.y., Matba'atu'1Mecma'i'l-'İlmiyyi'l-'Irâkî, 1983), I, 271.
} 
Kazvînî'nin iktibas tanımı sonraki belâgat âlimleri tarafından aynen devam ettirilmiştir. ${ }^{41}$ Bununla birlikte hutbelerde ve edebi yazı gibi nesir türlerinde yapılan alıntının iktibas, şiirde yapılan alıntının ise tazmîn olacağı şeklinde de bir görüş bulunmaktadır. ${ }^{42}$

İktibas, Hz. Peygamber zamanından beri Araplar tarafından bilinmektedir. Bu sanat Kazvînî́ye kadar iktibas, tazmîn, hüsnü't-tazmîn, îdâ' gibi terimlerle bilinirken daha sonra belâgat âlimleri nezdinde özellikle Telhîs şarihlerinde iktibas olarak yerleşmiştir. Bu dönemden itibaren ister nesirde olsun ister şiirde, iktibas denilince Kur'ân ve hadisten yapılan alıntı anlaşılmıştır.

\section{V. İktibasla İlgili Sanatlar}

İktibas sanatının terimleşme süreci Kazvînî ile sabit bir boyut kazanmıştır. Kazvînî iktibasın tanımını yaptıktan sonra onunla ilgili olan bazı terimlere de değinmiştir. $\mathrm{O}$, bu terimleri tazmîn, 'akd, hal ve telmîh olarak belirlemiştir. Bu terimler modern bazı belâgatçılar tarafından da ele alınmıştır. ${ }^{43}$ Şimdi bu terimlere biraz daha yakından bakmak faydalı

\section{A. Tazmîn}

Sözlükte bir şeyin bir yere konulması anlamına gelen tazmîn ${ }^{44}$ terim olarak bir şairin başkasının şiirinden bir parçayı kendi şiiri içerisinde zikretmesidir. Yapılan bu alıntı edebiyat ve belâgatçılar nezdinde meşhur değilse sahibinin belirtilmesi gerekmektedir. Meşhur ise belirtilmesi gerekmez. Aksi takdirde yapılan bu alıntı çalıntı (serikât-i şi'riyye) kapsamında değerlendirilir. Tazmînin en güzel formu, alıntı yapılan metne tevriye, teşbih gibi edebi nükteler ifade eden lafızların eklenmesidir. ${ }^{45}$ Ayrıca Kazvînî, tazminle ilgili bazı terimler zikretmektedir. Ona göre bir beyit veya daha fazla yapılan iktibas isti’âne, bir misra veya daha az bir kısmı iktibas edilirse bazen îdâ' bazen de rafv olarak isimlendirilmektedir. ${ }^{46}$

\footnotetext{
1 Sübkî, 'Arûsu'l-efrâh, II, 332; Teftazânî, el-Mutavvel, 723; es-Süyûtî, el-İtkân, 719; 'Isâmuddîn İbrahim b. 'Arabşâh İsferâyînî, el-Atvel şerhu Telhîsi miftâhi'l-'ulûm, (Beyrut: Dârü'l-Kütübi'l-'İlmiyye, 2001), 508-509.

42 Hamevî, Hizânetü'l-edeb, II, 459; Matlûb, Mu'cemu'l-mustalahâti'l-belâgryye, I, 272-273.

43 Kazvînî, el-Îzâh, 406; Meydânî, el-Belâgatü'l-'arabiyye, II, 536; Akdemir, Belâgat, 336-341.

44 İbn Manzûr, Lisânü'l-'Arab, XIII, 257.

45 Kazvînî, el-Îzâh, 412; Teftazânî, el-Mutavvel, 727; Bulut, Belâgat, 332; Akdemir, Belâgat, 336.

46 Kazvînî, el-Îzâh, 413.
} 


\section{Harîr̂̂’nin aşağıdaki beyti bu konuda verilen örneklerdendir: ${ }^{47}$}

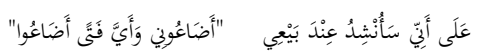

Bununla birlikte ben satıldığım gün şu mısrayı okuyacağım Değerimi bilmeyip beni kaybettiler, hem de nasıl bir genci kaybettiler.

Harîrî, beytin ilk mısrasındaki "okuyacağım" lafzıyla ikinci mısrayı tazmîn edeceğine işaret etmiştir. İkinci mısranın el-'Arcî (öl. 120/738) ya da Ümeyye b. Ebi's-Salt'a (öl. 5/626) ait olduğu ifade edilen aşağıdaki beyitten tazmîn edilmiştir: ${ }^{48}$

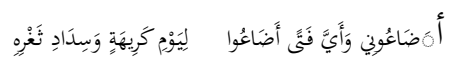

Değerimi bilmeyip beni kaybettiler, hem de nasıl bir genci kaybettiler.

Savaş olan ve de sınırdaki gediklerin korunması gereken bir günde.

Diğger bir örnek olarak İbn Ebi'l-Isba'1n (öl. 654/1256) aşağıdaki beyitlerini zikredebiliriz: ${ }^{49}$

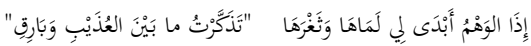

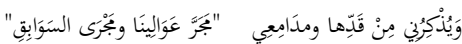

Hayal bana gösterdiği zaman (sevgilinin) esmer dudağını ve dişlerini

"Anımsadım ‘Uzeyb ve Bârik arasındakini”

Anımsattı hayal bana (sevgilinin) boyundan ve benim gözyaşlarımdan

"Mızraklarımızın çekilmesini ve yarış atlarının koşusunu" 50

Beyitlerin ikinci misraları Ebü't-Tayyib el-Mütenebbî́nin Seyfüddevle'yi övdüğü kasidesinin matla1dır. İbn Ebi'l-Isba'in yaptı̆̆1 tazmîn edebiyatçılar arasında meşhur olduğu için burada şiirin aslen Mütenebbî'ye ait olduğu belirtilmemiştir. İbn Ebi'l-Isba' burada tevriye sanatını icra ederek 'uzeyb lafzından ağız suyunun tatlılığını, ('uzûbe) bârik

\footnotetext{
47 Ebû Muhammed el-Kâsım el-Harîrî, Makâmatü'l-Harîrî, (Lübnan-Beyrut: Darü'l-Minhâc, 2014), 267; Kazvînî, el-Îzâh, 411; Bulut, Belâgat, 331.

48 Kazvînî, el-Îzâh, 411; Mustafa İsâmuddîn, et-Tansîsu'l-muntazar fî şerhi ebyâti't-Telhîs ve'l-Muhtasar, (İstanbul: Matbaa-i Âmire, 1843), 257.

49 İbn Ebi'l-Isba' el-Misrî, Tahrîru't-tahbîr fî sınâ'ati'ş-şi'r ve'n-nesr ve beyâni i'câzi'l-Kur'ân, thk. Hafnî Muhammed Şeraf, (Kahire: Vezâratü'l-Evkâf, 2012), 382.

50 'Uzeyb ve Bârik, Kufe yakınlarındaki iki yer ismidir. Beytin anlamı için bkz. Zihnî, el-Kavlü'l-ceyyid, 500501; Akdemir, Belâgat, 337.
} 
lafzıyla sevgilinin ön dişlerinin parlaklığını kastetmiştir. Ayrıca sevgilinin boyunu mızrakların çekilmesi ve kendi gözyaşlarının akmasını da yarış atlarının koşusuna benzeterek teşbih sanatını icra etmiştir. ${ }^{51}$

\section{B. ‘Akd}

Sözlükte bağlamak anlamına gelen 'akd ${ }^{52}$ terim olarak bir şairin başkasına ait bir nesri (düz yazıyı) iktibas yapmaksızın nazma çevirmesidir. $^{53}$

Ebü'l-'Atâhiye'nin (öl. 211/826) aşağıdaki beyti bu sanata dair güzel örneklerdendir:

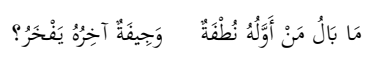

Başlangıcı nutfe olan kişiye ne oluyor Sonu leş iken övünüyor.

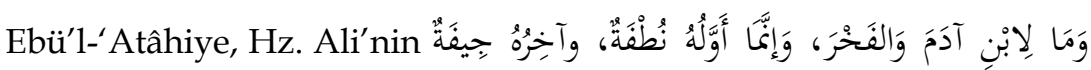
(İnsanoğluna ne oluyor da övünüyor, onun başlangıcı nutfe, sonu da leştir) sözünü nazma çevirmiştir. ${ }^{54}$

Yine Ebü'l-'Atâhiye'nin şu beyti 'akd sanatına verilen güzel bir örnektir:

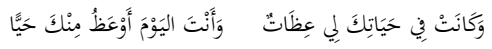

Senin hayatında benim için öğütler vardı

Bugün ise sen, benim için hayatta (olduğun duruma göre) daha çok öğüt verensin. 55

Rivayete göre Ebü'l-'Atâhiye, bazı bilginlerin İskender'in ölümü

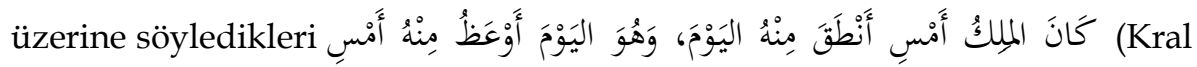
dün, bugüne göre daha çok konuşurdu, bugün ise o, düne göre daha çok öğüt alınacak kişidir) sözü nazma çevirmiştir. ${ }^{56}$

51 Meydânî, el-Belâgatü'l-'arabiyye, II, 540.

52 İbn Manzûr, Lisânü'l-'Arab, III, 296.

53 Kazvînî, el-Îzâh, 413; Teftâzânî, el-Mutavvel, 728; Meydânî, el-Belâgatü'l-'arabiyye, II, 541.

54 Kazvînî, el-Îzâh, 414; Bolelli, Belâgat, 440.

55 Ebü'l-'Atâhiye, bu beyti oğlu Ali'ye mersiye amaciyla nazmetmiştir. Bkz. el-Cârim ve Emîn, el-Belâgatü'lvâzıha, 198.

56 Kazvînî, el-Îzâh, 414. 


\section{Hal}

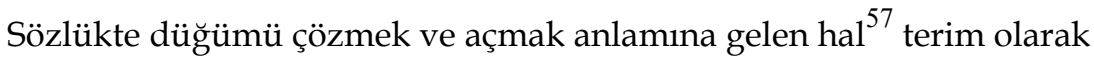
bir yazarın veya konuşmacının başkasına ait bir şiiri, nesre (düz yazıya) çevirmesidir. Bu sanatta önemli olan ortaya konulan söz diziminin aslını aratmayacak kadar özenli bir şekilde ve edebi zevk unsuru gözetilerek yapılmasıdır. Sözün aslındaki edebi güzelliğin korunmaması halinde ortaya çıkan nesir edebi ve belâğî değeri olmayan bir durum olarak kabul edilir. ${ }^{58}$ Hal sanatına Ziyâeddîn İbnü'l-Esîr'in (öl. 622/1225) şu sözü örnek olarak verilebilir:

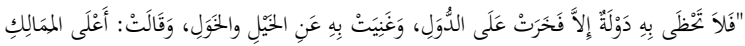

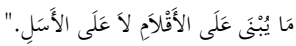

Bir devlet ona (kalem) sahip olursa diğer devletlere üstünlük sağlar. Ona sahip olmakla atlar, hizmetçiler ve uşaklara ihtiyaç duymayarak şöyle der: En üstün krallık mızraklar üzerine değil kalemler üzerine kurulandır.

İbnü'l-Esîr, Mütenebbî́nin aşağıdaki beytini nesre çevirerek en üstün krallıkların kalemler üzerine kurulanlar olduğunu beyan etmiştir. Mütenebbî ise nazmettiği şiirinde en üstün krallıkların mızraklar üzerine kurulanlar olduğunu iddia etmiştir. ${ }^{59}$

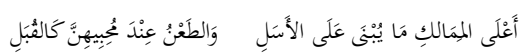

Krallıkların en üstünü mızraklar üzerine kurulandır

Mızrakları sevenler nezdinde (mızraklarla) yaralanmak öpücük gibidir.

\section{Telmîh}

Sözlükte gizli ve hızlı bir şekilde bakmak anlamına gelen telmîh ${ }^{60}$ terim olarak şiirde veya düzyazıda bilinen bir kıssa, şiir veya atasözüne gönderme yapmaktır. Burada önemli olan doğal bir üslup kullanılması ve telmîhte bulunulan lafızların zikredilmemesidir. Telmîhte bir düşünce veya

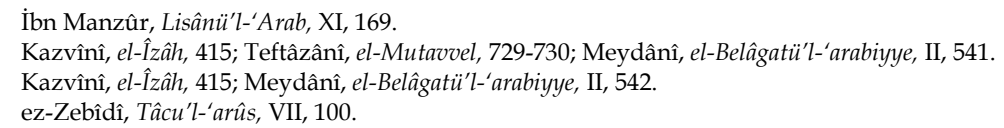


bir hayal o anlam için konulmuş kelimelerle doğrudan değil, dolaylı olarak ona işaret eden sözcüklerle anlatılmaya çalışılır. ${ }^{61}$

Bu sanata Kur'ân-1 Kerîm'den aşağıdaki ayet güzel bir örnektir:

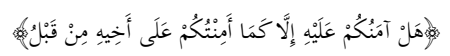

Daha önce kardeşini size emanet ettiğim gibi, şimdi de onu mu size emanet edeyim. 62

$\mathrm{Bu}$ ayet-i kerimede Hz. Yakup, oğullarının Hz. Yusuf'a yaptıkları ihanete telmîhte bulunarak onlara bir daha güvenemeyeceğini ifade etmiştir. $^{63}$

Ebû Temmâm'ın (öl. 231/846) aşağıdaki beytinde olduğu gibi:

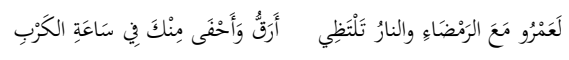

Vallahi ‘Amr dahi, kızgın toprakta ve ateşin tutuşması halinde Sıkıntı anında senden daha merhametli ve şefkatli.

Ebû Temmâm bu beytinde edebiyatçllar nezdinde meşhur olan aşağıdaki beyte telmîhte bulunmuştur:

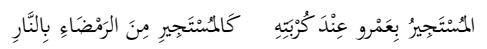

Sıkıntı anında 'Amr' dan yardım dileyen

Tıpkı kızgın toprağa karşı ateşten yardım dileyen gibidir.

Ebû Temmâm'ın beytinde İslam'dan önce yaşanan bir kıssaya işaret vardır. Rivayete göre Kuleyb adında bir şahıs bir dişi deveyi ok atarak öldürmüştür. Devenin sahibinin kabilesinden olan 'Amr ismindeki şahıs da bu olay üzerine Kuleyb'in peşine düsser. Kuleyb'i uzaktan görüp ona bir ok atar. Yaralanan Kuleyb, yanına gelen 'Amr'dan su isteyip yardım etmesini bekler. 'Amr, yardım edeceği yerde o anda Kuleyb'i öldürür. Bu olay üzerine Tağlib ve Bekr kabileleri arasında kırk yıl süren düşmanlık başlar. $\mathrm{Bu}$ hadise İslam'dan önceki Arap kabileleri arasında Cahiliye savaşları olarak bilinir. ${ }^{64}$

\section{VI. İktibas Sanatının Edebi Değeri}

\footnotetext{
1 Kazvînî, el-Îzâh, 415; Teftâzânî, el-Mutavvel, 730; Mehmet Ali Yekta Saraç, Klâsik Edebiyat Bilgisi Belâgat, (İstanbul: Gökkubbe, 2016), 282.

62 Yûsuf, 12/64.

63 Ahmed el-Hâşimî, Cevâhiru'l-belâga fi'l-me'ânî ve'l-beyân ve'l-bedî̀', thk. Yûsuf es-Samîlî, (Beyrut-Sayda: elMektebetü'l-'Asriyye, 2013), 342.

64 Kazvînî, el-Îzâh, 417; Meydânî, el-Belâgatü'l-'arabiyye, II, 542-543; Akdemir, Belâgat, 340.
} 
Her medeniyetin duygusal anlamda sözcülüğünü yaptığı bir edebiyatı vardır. Edebiyatın da din, tarih, tarihi hadiseler ve şahıslar, efsaneler, günlük hadiseler ve farklı bilim dalları vb. beslendiği pek çok kaynak vardır. $^{65}$ İslamî ilimlerin temel iki kaynağı̆, Kur'ân-1 Kerîm ve Hz. Peygamber'in hadisleridir. İslam medeniyeti bu iki kaynaktan beslenerek tefsir, fıkıh, hadis, dilbilim gibi disiplinlerin oluşmasına önemli katkılar sağlamıştır. Arap edebiyatı da Kur'ân' in nüzulünden sonra şekil ve muhteva bakımından değişikliğe uğramıştır. $\mathrm{Bu}$ dönemde şairler şiirlerinde Kur'ân'dan ve hadisten iktibaslar yapmış, Kur'ân'dan aldıkları anlamları şiirlerinde işlemişler ve üsluplarına yansıtmışlardır. İslamiyet, bu dönem edebiyatına bir yön vermiş, edebiyata anlam genişliği ve düşünce çeşitliliği kazandırmış, şair ve yazarlar Kur'ân ve hadisin üslûbundan etkilenmiş ve eserlerinde çoğunlukla bu üslûbu taklit etmeye önem vermişlerdir. Sadru'1İslam dönemi şairinin şiirlerindeki hayal ve tasvirlerin kaynağ1 Kur'ân'daki tasvirlerdir. ${ }^{66}$ Böylece Kur'ân ve hadislerin varlığının şairlerin şiirlerinde iktibas yapmaları için zengin bir nitelik ve içeriğe sahip olduğu ifade edilmelidir.

İbareye canlılık ve sıcaklık kazandırdı̆̆ı̆, sözü pekiştirip güzelleştirdiği için Kur'ân veya hadisten yapılan iktibaslar edebî bir sanat kabul edilmiştir. ${ }^{67}$ Kur'ân-1 Kerîm ve hadis-i şeriflerden yapılan iktibaslar kuşkusuz sözü güçlü kılıp söze belâgat ve lafzî güzellik kazandırmaktadır. Nitekim bir nesir veya nazımda iktibas edilen lafızlar parlayan bir 1şık ve aydınlık bir nur gibidir. Söz sahibi iktibas yaptı̆̆ında kendi sözleriyle iktibas edilen sözleri güçlü bir şekilde kaynaştırmış olur. Böylece söz, edebi değeri yüksek bir konuma ulaşır. ${ }^{68}$ Ayet ve hadislerden yapılan iktibas, hutbelerde, vaazlarda, hikmetli sözlerde, İslam'a davet eden ifadelerde insanları hayra ve erdemli olmaya yönlendirmede eşsiz bir edebî güce sahiptir. Ayrıca edebiyatçılar övgü, yergi, gazel, kardeşlik gibi çeşitli amaçlarla düşüncelerini güçlendirmek ve sözlerini süslemek için ayet ve hadislerden iktibas yaparlar. ${ }^{69}$ Kisaca ifade etmek gerekirse iktibas yapmaktaki edebî

\footnotetext{
65 Yeşildă̆, "Arap Şiirinde Ayet İktibası", 44.

66 Ömer Ferrûh, Târîhu'l-edebi'l-'arabî, (Beyrut, Dâru'l-'İlm li'1-Melâyîn, 1981), I, 256-257; Hannâ el-Fâhûrî, elCâmi' fi'l-edebi'l-'Arabî, (Beyrut-Lübnan: Daru'1-Cîl, 1982), 388-389; Kenan Demirayak, Arap Edebiyatı Tarihi II Sadru'l-İslâm Dönemi (01-41/622-661), (Erzurum: Fenomen Yayınları, 2009), 91-92.

67 Durmuş, "İktibas", 52.

68 Besyûnî Abdülfettâh Feyyûd, 'İlmu'l-me'ânî dirâse târihiyye ve fenniyye li usûli'l-belâga ve mesâili'l-bedî̀, (Kahire: Müessesetü'l-Muhtâr li'n-Neşr ve't-Tevzî́, 2013), 260-261.

69 Meydânî, el-Belâgatü'l-'arabiyye, II, 536.
} 
gaye okuyucu veya dinleyici üzerinde hoş bir tesir bırakmaktır. ${ }^{70}$ Nitekim bir muhatabın zihni Kur'ân'dan veya hadisten iktibasın yapıldığı bir söz ya da beyti işittiğinde aniden iktibasın yapıldığı yere odaklanacaktır. İktibas sanatının başarıyla icra edildiği ifade, dinleyenin kalbinde ve kulağında hoş bir nağme bırakacaktır. Alıntı yapılmaksızın söylenmiş bir sözün bu kadar etkili olamayacağı muhtemeldir.

İbnü'l-Esîr, edebî bir yazının kaleme alınması için bazı kıstaslar ortaya koymuştur. Ona göre bu alanda ilerlemek isteyen bir kimsenin öncelikle Kur'ân-1 Kerîm, hadis-i şerif, biçim ve içerik yönünden başarılı olan şairlerin şiirlerinden ezber yapması gerekmektedir. Daha sonra edebi yazı kaleme alan kişinin, yazılarında bu üç alandan iktibaslar yapması şarttır. Bu süreçte bazen başarılı olabileceği gibi başarısız olmak da mümkündür. Ancak en sonunda kişinin kalemi özgün bir yapıya kavuşacaktır. ${ }^{71}$

\section{Sonuç}

İktibas, Arap belâgatında bedî‘ ilminin muhassinât-ı lafziyye konuları kapsamında ele alınan bir sanattır. Bu sanat genel itibariyle nazım veya nesirde bir edibin Kur'ân-1 Kerîm veya hadis-i şeriflerden yaptığı alıntıyı ifade etmektedir. Çünkü Kur'ân-1 Kerîm ve hadis-i şerifler insan hayatıyla ilgili birçok alanda etkili olduğu gibi kendini edebiyat alanında da hissettirmiştir. Nitekim İslam'la müşerref olan edebiyatçılar duygu ve düşüncelerini ortaya koyarlarken ifadelerine güzellik ve canlılık katmak için bu iki kaynaktan beslenmişlerdir. Özellikle Sadru'l-İslam döneminde şair ve yazarlar şiir ve yazılarında Kur'ân ve hadislerden tasvirlere yer vermişlerdir. Edebiyatçılar Kur'ân-1 Kerîm'in eşsiz ve mucizevî üslubundan etkilenerek kendi yazılarında onu taklit etmeye çalışmışlardır.

Söz konusu ayet ve hadisler olunca iktibasın dinen caiz olup olmadiğ1 konusu da tartışılmıştır. Bu konuda genel itibariyle makbul, mübah ve caiz olmayan şeklinde üç kategoriden bahsetmek mümkündür. Hutbe hitabe, mev'iza ahid, na't gibi iktibaslar güzel amaçlara hizmet ettiği için makbul; gazel, risale ve kıssalardaki iktibaslar dünyevî maksatlar gözetilerek ortaya konsa da bir aykırılık teşkil etmediği için mubah sayılmış; Allah'ın zatına nispet ettiği ifadeleri insana uyarlayarak iktibasta bulunmak veya ciddiyetten uzak şiirlerde, müstehcen nazımlar içinde Kur'ân'dan ve

70 Mehmet Kaya Bilgegil, Edebiyat Bilgi ve Teorileri, (Erzurum: Salkımsöğüt Yayınevi, 2015), 251.

71 İbnü'l-Esîr, el-Meselü's-sâir, I, 91. 
hadisten iktibaslar yapmak ise uygun görülmemiştir. Bu üç itidalli görüşün dışında Malikiler aşırılığa kaçarak iktibasın yapılmasını haram olarak görmüş, hatta küfür derecesinde tehlikeli bulmuştur.

İktibasın tarihi serüvenini ele aldığımızda bu sanatın erken dönemlerden itibaren önemini koruduğunu görmekteyiz. Zira $\mathrm{Hz}$. Peygamber, dualarında ve hutbelerinde Kur'ân-1 Kerîm'den alıntılar yapmıştır. İslami dönem edebiyatında da îrad edilen hutbelerde Kur'ân ve hadisten alıntıların olması ortaya konan edebi ürünün değerli olması için adeta bir kıstas niteliği taşımıştır. Bu sanat terimleşme hüviyetini ise Kazvînî döneminde kazanmıştır. Kazvînîye kadar bu sanatı belâgatçılar tanımlarken tazmîn, hüsnü't-tazmîn, idrâc ve îdâ' gibi terimlere yer vermişlerdir. Kazvînîden sonraki süreçte ise iktibas terim olarak sabit bir yap1 kazanmıştır.

İktibasla yakından alakalı sanatlar belâgat ilminde tazmîn, 'akd, hal, ve telmîh olmak üzere dört kategoride ele alınmıştır. Tazmîn, bir şairin başkasının şiirinden bir parçayı kendi şiiri içerisinde zikretmesi; 'akd, bir şairin başkasına ait bir nesri iktibas yapmaksızın nazma çevirmesi; hal, bir yazarın ya da konuşmacının başkasına ait bir şiiri, nesre çevirmesi; telmîh ise şiirde veya düzyazıda bilinen bir kıssa, şiir ya da atasözüne gönderme yapmak şeklinde tanımlanmıştır.

İktibas, yerinde ve tabiî bir üslupla kullanıldığında anlamı teyit edip lafza üstün bir belâgat ve güzellik katmaktadır. Ayet ve hadisle süslenmiş bir sözü muhataplar işittiklerinde gönül ve zihin dünyalarında bir aydınlık ve canlanma meydana geleceği muhakkaktır. Günümüz dünyasında da ayet ve hadislerin nesiller tarafından algılanıp hayata tatbik edilmesi ihtiyaç duyulan bir husustur. Bu gayeyi gerçekleştirmek için ayet ve hadislerin edebî bir üslupla sunulması uygulanması gereken önemli bir yöntemdir.

\section{Kaynakça}

Akdemir, Hikmet. Belâgat Meânî-Beyân-Bedî̀. İstanbul: Nizamiye Akademi, 2016.

el-'Asker, Abdulmuhsin b. Abdilaziz. el-ïktibâs envâ'uh ve ahkâmuh. Riyad: Mektebetü Dâri'l-Minhâc, 2004.

Bilgegil, Mehmet Kaya. Edebiyat Bilgi ve Teorileri. Erzurum: Salkımsöğüt Yayınevi, 2015.

Bolelli, Nusrettin. Belâgat Meânî-Beyân-Bedî̀ Ilimleri. İstanbul: İFAV, 2015.

Bulut, Ali. Belâgat Meânî-Beyân-Bedî̀. İstanbul: İFAV, 2014. 
el-Câhız, Ebû Osman Amr b. Bahr. el-Beyân ve't-Tebyîn. 4 cilt. thk. Muvaffak Şihâbuddîn, Beyrut: Dârü'l-Kütübi'l-'̇lmiyye, 2009.

el-Cârim, Ali ve el-Emîn, Mustafa. el-Belâgatü'l-vâzıha. Dimaşk: Dâru'l-Kıbâ, tsz.

Demirayak, Kenan. Arap Edebiyatı Tarihi II Sadru'l-İslâm Dönemi (01-41/622-661). Erzurum: Fenomen Yayınları, 2009.

Durmuş, İsmail. “İktibas”. Türkiye Diyanet Vakfi İslâm Ansiklopedisi, İstanbul: Türkiye Diyanet Vakf1, 2000, XXII, 52.

el-Fâhûrî, Hannâ. el-Câmi' fi'l-edebi'l-'Arabî. Beyrut-Lübnan: Daru'1-Cîl, 1982.

Farhat, Kutaiba. “Arap Dili Edebiyatında Kur'an'dan İktibas”. Doktora Tezi, Ankara Yıldırım Beyazıt Üniversitesi Sosyal Bilimler Enstitüsü, Ankara 2019.

el-Ferâhîdî, El-Halîl b. Ahmed. Kitâbü'l-'ayn. 8 cilt. thk. Mehdî el-Mahzûmî. y.y.: Dâru ve Mektebetü Hilâl, tsz.

Ferrûh, Ömer. Târîhu'l-edebi'l-'arabî. 6 cilt. Beyrut: Dâru'l-'İlm li'l-Melâyîn, 1981.

Feyyûd, Besyûnî Abdülfettâh. 'İlmu'l-me'ânî dirâse târihiyye ve fenniyye li usûli'l-belâga ve mesâili'l-bedî̀. Kahire: Müessesetü'l-Muhtâr li'n-Neşr ve't-Tevzî', 2013.

el-Halebî, Şihabüddîn. Hüsnü't-tevessül ilâ sına'ati't-terassüll. Misır: el-Matbaatü'lVehbiyye, 1881.

94 el-Hamevî, İbn Hicce. Hizânetü'l-edeb ve ğâyetü'l-erab. 2 cilt. thk. 'İsâm Şakyû. Beyrut: Mektebetü'l-Hilâl, 2004.

el-Harîrî, Ebû Muhammed el-Kâsım. Makâmatü'l-Harîrî. Lübnan-Beyrut: Darü'lMinhâc, 2014.

el-Hâşimî, Ahmed. Cevâihru'l-belâga fi'l-me'ânî ve'l-beyân ve'l-bedî̀. thk. Yûsuf esSamîlî. Beyrut-Sayda: el-Mektebetü'l-'Asriyye, 2013.

el-Hillî, Safiyyüddin. Şerhu'l-kâfiyeti'l-bedî'iyye fì 'ulûmi'l-belâga ve mehâsini'l-bedî̀. thk. Nesîb Neşâvî. Beyrut: Dâru Sâdir, 1992.

İbnü'l-Esîr, Ziyâeddîn. el-Meselü's-sâir fî edebi'l-kâtibi ve'ş-şấ'ir. 2 cilt. thk. Muhammed Muhyiddîn Abdülhâmîd. Beyrut: Mektebetü'l-'Asriyye li't-Tibâ'a ve'nNeşr, 1999.

İbnü'l-Haccâc, Müslim. Sahîhu Müslim. 5 cilt. thk. Muhammed Fuâd Abdülbâkî. Beyrut: Dâru İhyâi't-Türâsi'l-'Arabî, tsz.

İbnü'l-Hanbel, Ahmed. Müsned. 50 cilt. thk. Şuayb el-Arnût vd. y.y., Müessesetü'rrisâle, 1999.

İbn Manzûr, Ebü'l-Fazl Muhammed b. Mükerrem. Lisânü'l-'Arab. 15 cilt. Beyrut: Dâru Sâdir, 1993.

el-Isfahânî, er-Râgıb. Müfradâtü elfâzi'l-Kur'ân. thk. Safvân Adnan Râvevdî. Dimaşk: Dârü'l-Kalem, 1997. 
İsâmuddîn, Mustafa. et-Tansîsu'l-muntazar fì şerhi ebyâti't-Telhîs ve'l-Muhtasar. İstanbul: Matbaa-i Âmire, 1843.

İsferâyînî, 'Isâmuddîn İbrahim b. 'Arabşâh. el-Atvel şerhu Telhîsi miftâhi'l-'ulûm. 2 cilt. Beyrut, Dârü'l-Kütübi'l-'İlmiyye, 2001.

el-Kalkaşendî, Ahmed b. Ali. Subhu'l-a'şâ fî sinâ'ati'l-inşâa. Beyrut: Dârü'l-Kütübi'l'ilmiyye, tsz.

el-Kazvînî, el-Hatîb. el-Îzâh fí 'ulûmi'l-belâga. thk. Muhammed Abdülkâdir el-Fâzilî. Beyrut: el-Mektebetü'l-'Asriyye, 2009.

el-Mağribî, İbnü'l-Kattân. Beyânü'l-vehm ve'l-îhâm fî kitabi'l-ahkâm. 6 cilt. thk. Hüseyin Ayet Sa'îd. Riyad: Dâru Taybe, 1997.

Matlûb, Ahmed. Mu'cemu'l-mustalahâti'l-belâgryye ve tatavouruhâ. 3 cilt. y.y. Matba'atu'l-Mecma'i'l-'İlmiyyi'l-'Irâkî, 1983.

el-Meydânî, Abdurrahman Hasan Habenneke. el-Belâgatü'l-'arabiyye üsüsühâ ve 'ulûmuhâ ve fünûnuhâ ve suverun min tatbîkâtihâ bi-heykelin cedidin min tarifin ve telîd. Dimaşk: Dârü'l-Kalem, 2013.

el-Mısrî, İbn Ebi'l-Isba'. Tahrîru't-tahbîr fì sınâ'ati'ş-şi'r ve'n-nesr ve beyâni i'câzi'l-Kur'ân. thk. Hafnî Muhammed Şeraf. Kahire: Vezâratü'l-Evkâf, 2012.

en-Nüveyrî, Ebü'l-Abbâs Şihâbüddîn. Nihâyetü'l-ereb fî fünûni'l-edeb. 33 cilt. Kahire: Dârü'l-Kütüb ve'l-Vesâiki'l-Kavmiyye, 2002.

er-Râzî, Fahreddîn. Nihâyetü'l-îcâz fì dirâyeti'l-i'câz. thk. Nasrullah Hacımüftüoğlu. Beyrut: Dâru Sâdir, 2004.

es-Sa'îdî, Abdülmüte'âl. Buğyetü'l-Îzâh li Telhîsi'l-miftâh fì 'ulûmi'l-belâga. 4 cilt. y.y: Mektebetü'l-Âdâb, 2005.

Saraç, Mehmet Ali Yekta. Klâsik Edebiyat Bilgisi Belâgat. İstanbul: Gökkubbe, 2016.

es-Sicistânî, Ebû Dâvûd. Sünenü Eb̂̂ Dâvîd. 4 cilt. Beyrut: Dârü'l-Kütübi'l-'İlmiyye, tsz.

es-Sübkî, Ahmed b. Ali b. Abdilkâfî Ebû Hâmid Bahâeddîn. 'Arûsu'l-efrâh fî şerhi Telhîsi'l-miftâh. 2 cilt. thk. Abdülhamîd Hindâvî. Beyrut: el-Mektebetü'l'Asriyye, 2003.

es-Süyûtî, Celâleddîn. Şerhu 'ukûdi'l-cümân fi'l-me'ânî ve'l-beyân. thk. İbrahim elHamedâni, Emîn Lukmân el-Habbâr. Beyrut: Dârü'l-Kütübi'l-'İlmiyye, 2011.

el-i̇tkân fî̀ 'ulûmi'l-Kur'ân. thk. Merkezu'd-dirâsâti'l-Kur'âniyye. y.y., Vezâratü'ş-şuûni'l-İslâmiyye ve'l-evkâf ve'd-Da'veti ve'l-İrşâd, tsz.

. Muhtasaru'l-me'ânî. 2 cilt. thk. Hind Mahmûd Hasan. Pakistan: Mektebetü'1Büşrâ, 2012.

et-Teftâzânî, Sa'duddîn Mesud b. Ömer. el-Mutavvel şerhu Telhîsi miftâhi'l-'ulûm. thk. Abdülhamîd Hindâvî. Beyrut-Lübnan: Dârü'l-Kütübi'l-'Illmiyye, 2007. 
et-Tilimsânî, Şehabettin Ahmed b. Muhammed el-Makrî. Nefhu't-tîb min gusni'lendülüsi'r-ratîb. 8 cilt. thk. İhsan Abbâs. Beyrut: Dâru Sâdir, 1997.

Yeşildağ, Abdussamed. “Arap Şiirinde Ayet İktibası”. Şarkiyat Mecmuası, 27/2 (2015): 43-66.

ez-Zebîdî, Muhammed Murtezâ el-Hüseynî. Tâcu'l-'arûs min cevâhiril'l-kâmûs. 40 cilt. thk. Abdüssettâr Ahmed Ferrâc. Kuveyt: Dârü'l-Hidâye, 2004.

Zihnî, Mehmed. el-Kavlü'l-ceyyid fì şerhi ebyâti't-Telhîs ve Şerhayhi ve Hâşiyeti's-Seyyid. İstanbul: Matbaa-i Âmire, 1910.

ez-Zürâ̂, Ebû Abdillâh Şemsüddîn Muhammed b. Ebî Bekr b. Eyyûb. el-Fevâid elMüşevvik ilâ 'ulûmi'l-Kur'ân ve 'ilmi'l-beyân. Lübnan: Dâru'l-Kutubi'l'Ilmiyye, tsz. 


\section{İbrahim Kara}

\section{The Art of Quoting in Arabic Rhetoric}

Citation/@: Kara, İbrahim, The Art of Quoting in Arabic Rhetoric, Artuklu Akademi, 2021/8 (1), 77-98.

\section{Extended Abstract}

When quote is mentioned in Arabic literature and rhetoric, quotations from verses or hadiths in poetry and prose generally comes to mind. As a result of the Arab society's meeting a new religion, changes have come out to be inevitable in literature, like in many other fields. Poets and writers who were affected by the unique eloquency of the Quran made quotations from verses and hadiths in order to add literary efficiacy to their expressions and themes. Thus, it is aimed that the principles brought by new religion will be covered in the field of literature and have a good effect on the addressees by this paper.

Quote means aizle, to ask for charity and knowledge in the dictionary. The word quote is mentioned in two places in the Quran in different forms. This word also means taking embers of fire and making use of light in the Holy Quran.

When performing this art in poetry or prose, it should not be obvious that the quotation is made. The expressions that are certain that the quotation is made from the Quran or hadiths are not considered within the scope of the art of quotation. While applying to this art, some minor changes are tolerated in poetry due to the necessity of meter and rhyme. While quoting from verses or hadiths, if the whole text is quoted, it is called "full quotation" even if half or part of the text is quoted it is called "short quotation".

The two main sources of Islamic sciences are the Quran and the hadiths of the Prophet. Islamic civilization fed on these two sources and made significant contributions to the formation of disciplines such as tafsir, fiqh, hadith, and linguistics. Arabic literature has also changed in terms of form and content after the Qur'an was adopted. In this period, poets made quotations from the Qur'an and hadith in their poems, processed the meanings from the Qur'an in their poems and reflected them in their styles. Islam drew a direction to the literature of this period, brought a breadth of meaning and diversity of thought to literature, poets and writers were influenced by the style of the Quran and hadith and mostly gave importance to imitating this style in their works. The source of the imaginations and depictions in the poems of the Islamic period poet are the depictions in the Quran. Thus, it should be stated that the existence of the Quran and hadiths has a rich quality and content for poets to quote in their poems.

Quotations made from the Quran or hadith have been accepted as a literary art as it gives vitality and efficiacy to the phrase and reinforces and enhances the word. Quotations made from the Quran and hadiths undoubtedly make the word strong and give rhetoric and verbal beauty. As a matter of fact, words 
quoted in a prose or verse are like a shining light and a luminous light. When the spokesperson quotes, he strongly fuses the words quoted with his own words. Thus, the word reaches a high literary value. Quotations made from verses and hadiths have a unique literary power in guiding people to be benevolent and virtuous in sermons, religious lectures, wise words and expressions that invite the audience to Islam. In addition, writers make quotations from verses and hadiths to strengthen their thinking and embellish their words for various purposes such as praise, satire, gazelle, brotherhood. In short, the literary purpose of quoting is to have a pleasant influence on the reader or the listener.

The art of quote is an art known since the early years of Islam. As a matter of fact, the Prophet made quotations from the Quran in his prayers and sermons. For this reason, the presence of a part of God's word in the speech of a person who reads a sermon is a criterion in terms of literary value. In this direction, a sermon that does not have a quotation from the Quran is considered unusable. Because the sermon read by Imran b Hattan was highly appreciated by literary experts, it was concluded that this person would be the greatest orator of the Arabs if there was a quote from the Quran in this sermon.

There are various opinions regarding the religious decree of the quotation. In the Maliki sect, it is considered haram and even dangerous to the extent of blasphemy. In the Shafii sect, on the other hand, there was no harm in making the quotation. However, quotations such as khutba, naat and advice are acceptable; qotations in ghazels, treatises and stories are regarded as permissible. It is not considered permissible to make quotations from the quran and hadith by adapting the expressions attributed to the essence of God to humans, in poems far from serious and in obscene poetry.

Scholars such as Fahreddin al-Razi, Shihabuddin al-Halabi, an-Nuwayri, Ibn Qayyim al-Jawziyya and al-Hateeb al-Kazvini defined this art in their works. According to Fahreddin al-Razi, quoting is the addition of a word or verse from the Quran to decorate the word and increase its value. On the other hand, Shihabuddin al-Halabi defined this art under the title of "husn at- tazmeen" as adding an expression from the Quran, hadith, parable or couplet to the words of the owner. When the historical process is examined, this art has been mentioned by rhetoric scholars with terms such as iqtibas, tazmeen, husn attazmin, idaa. However, in Kazvini and the following period, this art was expressed with the word quotation.

The arts that are closely related to quotation are discussed in four categories in rhetoric, namely "tazmin, 'akd, hal, and talmeeh". Tazmin is a poet's recitation of a part of someone else's poem in his own poem; 'Akd is the conversion of a prose belonging to someone else to a poetry without quoting; hal, is an author or speaker converting someone else's poem into a prose; Talmeeh is defined as referring to a story, poem or proverb known in poetry or prose. 